\title{
Innovation in Industrial Clusters: a Survey of Footwear Companies in Brazil
}

\author{
Hélcio Martins Tristão', Pedro Carlos Oprime², Daniel Jugend ${ }^{3}$, Sérgio Luis da Silva ${ }^{2}$
}

\begin{abstract}
The aim of this study is to characterize the relationships in innovation and business clustering processes in the productive chain of small and medium enterprises (SME) of Brazil. The object of study are SMEs the local procuctive cluster of the shoes in Franca, State of São Paulo. The conceptual model developed is based on the following constructs: vertical integration, innovation and characteristics of the cluster, and it is focused on identifying the agents that act predominantly in product innovation processes in the cluster. A survey was conducted. It was found that there is cooperation between the companies in the productive arrangement studied, and that shoe manufacturers are those who, predominantly, stimulate innovation within the cluster.
\end{abstract}

Keywords: innovation, cluster, footwear sector.

\footnotetext{
'Centro Universitário de Franca, Av. Major Nicácio, 2433, Franca, SP, Brazil. e-mail: helciotristao@hotmail.com. Phone: 55 I6 37 I 34605 ${ }^{2}$ Department of Production Engineering - Federal University of Sao Carlos (UFSCar). Rod.Washington Luiz, km 235, I3565-905 São Carlos SP - Brazil. E-mail: pedro@dep.ufscar.br. Phone 551633518237

${ }^{3}$ Department of Production Engineering - Universidade Estadual Paulista (Unesp).Av. Eng. Luiz Edmundo Carrijo Coube I4-0I, Bauru - SP - Brazil. e-mail: daniel@feb.unesp.br. Phone: 55 I4 31036I22
} 


\section{Introduction}

Companies need to continuously improve their performance to remain competitive, which justifies the constant demand for new technologies related to products, processes, and management. Riis, Johansen and Waehrens (2007) highlighted that the economic environment in which companies operate has forced them to introduce changes in their product lines in order to gain positioning in new market segments. In addition, there have been investments in the modernization of manufacturing equipment, and the adoption of new policies towards suppliers in addition to reaping the benefits of vertical cooperation in the productive chain and in the relationships with the market in terms of the symmetry of competitive strategies.

Therefore, there has been a transition from a resource-based to a knowledge-based production. In this paradigm, seeing competitiveness from a systemic rather than individual point of view is a more effective approach since the problems are solved by multidisciplinary teams. This perspective, however, needs further analysis considering that different groups of companies have different approaches to management. This implies adopting different strategies to face a more competitive environment. As the center of this discussion, innovation is seen from different points of view by different businesses. Based on the assumption that there is an asymmetry in the management of innovation and in the correlation between groups of companies in the same tier of the productive chain, this study aims at addressing innovation in the context of industrial clusters.

The purpose of this paper is to investigate whether the innovations result from actions of manufacturers or suppliers or from joint actions by those companies. In addition to this investigation, this study seeks to identify the source that added the most or least value to products via innovation. Specifically, we sought to identify statistically the differences among three groups of companies in the footwear cluster of the city of Franca. This research provides an accurate portrayal of the technological development of the footwear sector in the State of São Paulo, Brazil.

For over a century the city of Franca, in the state of São Paulo, south of Brazil, has stood out as an important production center of footwear serving both national and international markets. However, it has increasingly been influenced by competitors, mainly those from Asia, in terms of prices, types of products, and even innovations (Hilsdorf, Rotondaro and Pires, 2009). Hence, the companies in this sector seek to develop greater competitive ability, which involves a series of corporate actions. Such actions should include: sales strategies, manufacturing process and product development management, improvement of labor productivity, skills and ability development, innovation process capacity, integration between business, and government policies for this sector.

The first session of the present study presents the topics discussed, the object of study, and its expected contributions. The second session deals with the theoretical aspects involving the dynamics of innovation in industrial clusters. The third session presents the research methods, the fourth analyzes the results of the field research, and the last session presents the conclusions.

\section{Theoretical framework}

\section{I Innovation and Industrial Clusters}

Burgelman, Mandique, and Wheelwright (200I) define innovation as a process which is characterized as an act of introducing something new. This process involves the generation, adoption, implementation, and incorporation of new ideas and practices in order to create wealth. Given this definition, knowledge management plays a central role since it is the means to increase organizational capacity focusing on achieving efficiency through the creation, dissemination, and adoption of science and technological knowledge.

Another concept of technological innovation that has received attention is known as open innovation, which has been disseminated in the literature of the area, because with the current pace of technological change it has been very difficult for companies to ensure their competitiveness through unique and exclusive internal development of new technologies. This concept of Open Innovation refers to a combination of internal and external ideas within systems and architectures related to the business (Idrissia, Amaraa and Landrya, 2012). Thus, the business model uses internal and external ideas to create value making the R\&D an open system (Chesbrough, 2003).

Innovation through industrial clusters can be defined as a way to increase the competitiveness of small and medium enterprises by reaping the benefits generated by the local structures and synergies via cooperative relationship(Idrissia, Amaraa and Landrya, 2012). The clusters provide alliances, which among other things promote flexibility in terms of production volume and variety, reductions in investment costs, reduction in transaction costs and increase in operational efficiency, increased bargaining power, and the development of technology innovation processes (Rabellotti, 1999; Solvell, Ketels and Lindqvist, 2008; Bas, Amoros and Kunc, 2008).

The synergy of industrial clusters is also recognized as a relationship network including companies in the same industry sector and that offer them the possibility to achieve 
innovation and improve product and process development. According to Kuei-Hsien, Miles and Ghung-Shing (2008), network relationships can differentiate the value of the productive chain when the partners are engaged in activities of common interests allowing the improvement of pro-active actions in the final product or service, which creates a stimulating environment for the innovation process.

Therefore, there has been great interest in developing these networks of companies (Idrissia,Amaraa and Landrya, 2012), which can be called clusters, industrial districts, or agglomeration of companies. Several studies have been published on this subject, and among them some stand out such as those that address the relationship between the region's socio-cultural aspects and the development of clusters (Oliver and Porta, 2005), the relationship between interactivity and performance and cooperation between small and medium enterprises (Visser, 1999; Karaev, Lenny and Szamosi, 2007; Oprime et al., 2009), the creation of technology innovations and their spread within the clusters (Bell and Albu, 1999; Baptista, 2000; Mohannak, 2007; Mason and Castleman, 2008), and the use of information technology in regional development (Hoffman, Gregolin and Oprime, 2004; Mason, Castleman and Parker, 2008).

Oliver and Porta (2006) point out that without the improvement of their strategies, companies tend to have limitations on the use of territorial resources provided by the participation in the clusters. It is understood, therefore, that innovation, as an effective means of creating wealth depends on a marketing strategy that reaps the potential benefits of the cluster. Similarly, Shiele (2008) argues that the territorial actions in the clusters have favoured marketing in regional development, but companies lack integration strategies to participate in the cluster. In addition, there are some difficulties in forming a cluster, such as trust, which is a major constraint. Another aspect is the view of managers about grasping opportunities offered by a cluster to reduce transaction costs in operations and in product development.

Petruzzelli, Albino and Carbonara (2007) indicate that regional innovation can be considered as the result of the capabilities to activate, develop, and sustain the processes of managing knowledge since the local and regional capacities of the innovation process are related to the skills of the geographic area to produce and market a flow of innovative technology. This ability depends on the common infrastructure of the innovation process and a favorable environment for innovation, in addition to a strong link between the regional acotors. However, what is observed in some clusters in Brazil are barriers hindering technology and innovation from being tools for competitiveness, especially by small and medium-sized enterprises belonging to traditional sectors of industry (Oprime et al., 2009). Tacit knowledge developed within the cluster is an asset that should have a governance of innovation and competitiveness generation (Shiuma and Lerrer, 2008). Therefore, knowledge asset corresponds to some regional resource that offers qualification to transform the resources available into regional competitive advantages. This asset is characterized by Bas, Amoros and Kunc (2008) as human capital, relationship capital, structural capital, and social capital. Human capital includes knowledge of different actors within a region, which may be tacit or explicit and mean personal knowledge, but it can also be collective knowledge.

\subsection{Technology innovation of brazilian footwear in- dustries and hypotheses of research}

Technological innovation is a matter on the agenda of all countries. The report by the OECD (2008), addresses the issue of innovation by drawing an overall picture of the global industry competition resuting from scientific and technological discoveries. Based on other studies, especially that of

\begin{tabular}{|l|ll|}
\hline \multicolumn{1}{|c|}{ Highlights } & \multicolumn{1}{c|}{ Overall picture of the global industry competition between 2001 and 2006} \\
\hline Level of investiment & $\begin{array}{l}\text { OECD countries: USA }=-3 \% \text {; United Kingdon }=-2 \% ; \\
\text { Counries outside of OECD: China; Russian Federation; South Africa, and India = increased } \\
\text { investiments } \\
\text { Brazil = manitained investiments }\end{array}$ \\
\hline Patent registration & - & $\begin{array}{l}\text { Increased patent registration records : China; India; and Brazil } \\
\text { Decreased patent registration records : USA, Europian Union; Russian Federation and South }\end{array}$ \\
\hline Scientific publications & Africa & Increased: China; India; and Brazil \\
& - & Decreased: Europian Union; USA; Japan; and Russian Federation \\
\hline $\begin{array}{l}\text { Level of government R\&D } \\
\text { spending (subsidies) }\end{array}$ & $\begin{array}{l}\text { The top 10 countries: 1) Spain, 2) Mexico and France, 3) China; 4) Portugal, 5) Czech Republic, 6) } \\
\text { India; 7) Brazil, 8) Singapore, 9) Norway, and 10) South Korea }\end{array}$ \\
\hline
\end{tabular}

Table I: Results from the OECD research, 2008 (Source:Adapted from OECD, 2008).

ISSN: 07 I8-2724. (http://www.jotmi.org)

Journal of Technology Management \& Innovation (c) Universidad Alberto Hurtado, Facultad de Economía y Negocios. 
Neely, Adams and Kennerly (2002), the study points to the need for a new corporate agenda since the individual financial performance is not enough anymore. This report shows interesting aspects about the level of investment in R\&D, patent registrations, scientific publications, and government R\&D budgets. Table I shows part of this research.

However, these studies focus on cultural issues. They indicate that it is difficult to establish performance measures to support the management of new social and technological demands. Although these aspects are incorporated into the corporate strategies of many companies, they are not properly absorbed by the management systems. Even experienced managers have struggled to address appropriately the management of intellectual capital, research and development, and technological innovation.

According to Medori and Steeple (2000), these new demands, come from natural global competition but with more social and environmental restrictions. Competition is also based on the power of customer choice, so the businesses need three types of capacity: i) concept domain, ii) technological competence, and iii) social and economic connections with the global market.

At this stage, mastering the technological processes of obtaining, analyzing, and disseminating information is critical to business success. The desired outcome is to transform information into knowledge and knowledge into skills. Technological innovation always operates within an inseparable context between technology and society. An available technology is not simply reproduced without understanding and adapting to the social context in which it will be inserted. This aspect is referred to by some authors as one of the main bottlenecks of technological innovation (Hsu et al.,2008).

Hsu et al. (2008) argue that failures in the information process are a critical factor in the relationship between customer and supplier. This occurs when the company does not have a proper management of this relationship, which hinders the flow of information and knowledge within the company and between companies affecting the marketing strategies. Managers should investigate not only the dimension of the company's internal information system but also its external dimension.

In a study on the supply chain governance, Ghosh and Fedorowicz (2008) emphasize that the level of trust between partners is a critical factor in the information, knowledge, and competence transformation process. They believe that both governance and coordination must be evaluated in terms of confidence, bargaining power, contracts, and information sharing between companies. According to them, this allows the collective learning that leads to higher innovation rates. The OECD (2008) presents three types of innovation patterns resulting from empirical analysis. The first pattern or mode of innovation involves any form of innovation for a new market generated from a homemade technology research and development or patents. The second mode of innovation occurs with the acquisition of machinery equipment for the modernization of the plant. The third results from the cooperation of businesses through business network models such as industrial clusters. This last mode of innovation is characterized as a broad innovation process in which companies operate; it is known as wider innovation mode, and it is the closest to the object of this study.

According to the OECD, there is not a single form of innovation due to the differences in standards related to specific competitive and comparative advantages of each business. Innovation in firms goes beyond technology including policies to cope with diversity as well as social and cultural specificities. Furtado and Carvalho (2005) present a classification of the technological innovation dynamics by economic sectors in the Brazilian economy.

This classification is based on the OECD report (2008) that uses indicators of R\&D intensity (R\&D expenditurevalue added, or R\&D expenditure-manufacturing) as the classification parameter.The economic sectors are classified into four groups according to their technology innovation intensity. The leather footwear industry is classified as low technology intensity, but this industry is very important in the aspects economic and social. This and other intensity indicators of innovation are shown in table 2.

\begin{tabular}{|l|l|}
\hline \multicolumn{1}{|c|}{ Technology Intensity Groups } & \multicolumn{1}{c|}{ Sectors } \\
\hline Group 1- High Technology Intensity & Aerospace, pharmaceutical, computer, electronic and telecommunications, \\
\hline $\begin{array}{l}\text { Group 2-Medium and High Technology } \\
\text { Intensity }\end{array}$ & $\begin{array}{l}\text { Electronic materials, automobile, chemical, pharmaceutical, railray and transportation } \\
\text { equipment, machinery and equipment. }\end{array}$ \\
\hline $\begin{array}{l}\text { Group 3- Medium and Low Technology } \\
\text { Intensity }\end{array}$ & $\begin{array}{l}\text { Shipbuilding, rubber and plastic products, coke, refined petroleum products and nuclear fuel, } \\
\text { other non-metallic products; metallurgy and metal products. }\end{array}$ \\
\hline Group 4- Low Technology Intensity & $\begin{array}{l}\text { Recycling industry and others, wood, paper and cellulose, publishing and printing, food, } \\
\text { beverages and tobacco, textiles and clothing, leather and footwear. }\end{array}$ \\
\hline
\end{tabular}

Table 2: Classification of technology intensity of economy sectors (Source:Adapted from Furtado and Carvalho, 2005).

ISSN: 07I 8-2724. (http://www.jotmi.org)

Journal of Technology Management \& Innovation (c) Universidad Alberto Hurtado, Facultad de Economía y Negocios. 
Another indication of the intensity of technology innovation of the leather footwear sector is found in the innovation survey database conducted by IBGE, denominated Pintec 2008 , which presents a classification of the level of technology innovation intensity of industries in Brazil by sectors, as shown in Table 3.

The three means groups of footwear companies are considered in this study: i) shoe manufacturers; ii) sole manufacturers, iii) and tanneries. This study considers that there is a local production system or a cluster in the footwear industry the region of Franca - State of São Paulo, as proposed by Porter (1999), and that strategic alliances with the aim of increasing the systemic competitiveness of the local productive chain are developed within the cluster.The hypothesis to verify which factors represent the characteristics of innovation and cooperation processes in the industrial complex under study were extracted from the theoretical framework of vertical integration, clustering, and innova- tion process (session two). The contextualization of the hypothesis is that the variables of the local Innovation system are asymmetric and explain the characteristics of the local productive chain (figure I).

\section{Research method}

According to the literature, have been identified twelve constructs (Table 4). Since the variables are qualitative and ordinal, non-parametric methods were applied, whose results are based on personal judgments and opinions (Triola, 2005). The research approach adopted was quantitative, which was operationalized through a field survey. A closed questionnaire format with responses based on judgments and perceptions of respondents was used as a research tool.A qualitative ordinal scale structured with questions formulated from the constructs, based on the theoretical framework presented in this study, was used. The constructs and their scales were validated using statistical tests such as Cron-

\begin{tabular}{|c|c|c|c|c|c|c|c|c|c|}
\hline \multicolumn{2}{|c|}{ R\&D efforts of the processing industry by sectors - Brazil 2000} \\
\hline & $\begin{array}{c}\text { Industrial } \\
\text { processing } \\
\text { value }\end{array}$ & Internal R\&D & $\begin{array}{c}\text { Exter- } \\
\text { nal R\&D }\end{array}$ & $\begin{array}{c}\text { Total } \\
\text { R\&D }\end{array}$ & $\begin{array}{c}\text { Internal } \\
\text { R\&D }\end{array}$ & $\begin{array}{c}\text { Total } \\
\text { R\&D }\end{array}$ & $\begin{array}{c}\text { Internal } \\
\text { R\&D } \\
\text { VTI }\end{array}$ & $\begin{array}{c}\text { Total } \\
\text { R\&D } \\
\text { VTI }\end{array}$ & $\begin{array}{c}\text { External } \\
\text { Expenditure }\end{array}$ \\
\hline $\begin{array}{c}\text { textile, } \\
\text { cothing, and } \\
\text { footwear }\end{array}$ & $16.914,909$ & 101.262 & 9.898 & 111,16 & 2,73 & 2,56 & 0,60 & 0,66 & 8,90 \\
\hline
\end{tabular}

Table 3: Classification of technology intensity of the textile, clothing, and footwear sectors.Source:Adapted from Carvalho and Furtado (2005) and and Brazilian Institute of Geography and Statistics - IBGE (2008)

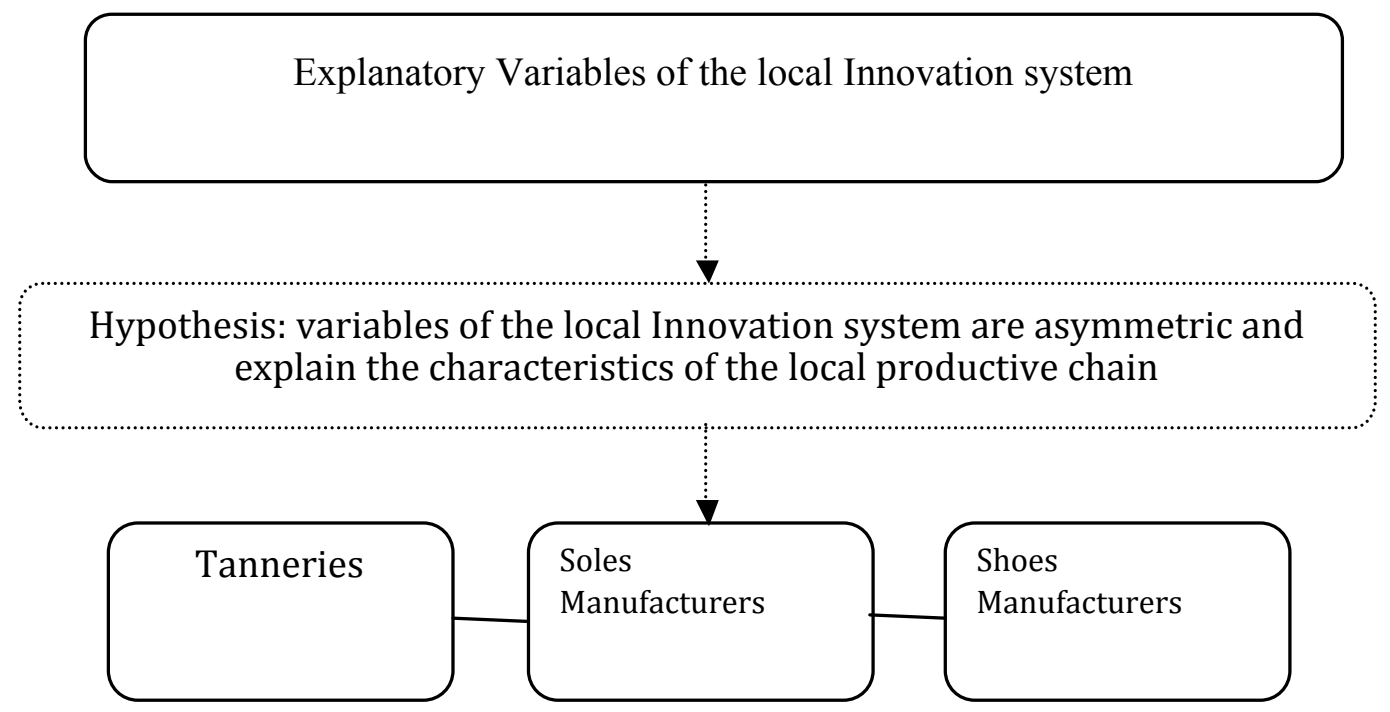

Figure I: Conceptual Model and research hypothese.

ISSN: 07 I8-2724. (http://www.jotmi.org) 
bach's alpha, which measures the degree of dependence between variables, and factor analysis, a multivariate method, characteristic of this type of study (Basilevsky, 1994). Statistica $®$ version 9 software was used for the statistical analyses. The object of study of this research is the footwear cluster in the city of Franca-SP, which has over a thousand companies with different roles in the shoe production chain. This special cluster was chosen, in part, based on statements made by some authors such as Tosi (1998); Suzigan et. al. (200I) and Tristão (2000), who consider it as one of the most important clusters in the State of São Paulo and in the country. Such importance is corroborated by data from the MDIC / SECEX (Ministry of Development, Industry, and Foreign Trade of Brazil), which points out that in 2008 the footwear cluster of Franca produced 28.7 million pairs of shoes and earned an export revenue of U.S. $\$ 4.5$ million.
The population of interest was classified into three groups: shoe manufacturers, sole manufacturers, and tanneries. A total of 36 companies were chosen randomly according to three groups of manufacturers: 8 leather processing companies, commonly referred to as tanneries, 8 sole manufacturers, and 20 shoe manufacturers.

Before visiting the companies, those in charge of product development were identified and contacted in order to explain the purpose of the research and thus schedule the visits. In order to adjust the questions, a pre-test was performed in some companies. The sample profile is shown in Table 3b.

The research tool was organized into two parts. In the first one, the respondents characterize the company, and in the second they responded to 20 closed questions on a Likert

\begin{tabular}{|c|c|c|c|c|}
\hline \multirow[t]{3}{*}{ Type of company } & \multicolumn{4}{|c|}{ Profile characteristics } \\
\hline & \multicolumn{4}{|c|}{ Age of the company (years) } \\
\hline & Less than 10 & Between 10 and 20 & Between 21 and 30 & Over 30 \\
\hline Shoe & 05 companies & 07 companies & 02 companies & 04 companies \\
\hline Tanneries & - & 02 companies & 01 company & 05 companies \\
\hline \multirow[t]{3}{*}{ Sole } & 01 company & 04 companies & 03 companies & - \\
\hline & \multicolumn{4}{|c|}{ Number of employees } \\
\hline & Less than 10 & Between 10 and 20 & Between 30 and 100 & Over 100 \\
\hline Shoe & 02 companies & 08 companies & 08 companies & 02 companies \\
\hline Tanneries & - & - & 01 company & 07 companies \\
\hline \multirow[t]{3}{*}{ Sole } & 01 company & 01 company & 04 companies & 02 companies \\
\hline & \multicolumn{4}{|c|}{ Predominant management model } \\
\hline & Centralized ownership & $\begin{array}{l}\text { Decentralized department } \\
\text { model }\end{array}$ & \multicolumn{2}{|c|}{$\begin{array}{c}\text { Participatory or } \\
\text { Centralized management* }\end{array}$} \\
\hline Shoe & 16 companies & 03 companies & \multicolumn{2}{|c|}{01 company } \\
\hline Tanneries & 05 companies & 02 companies & \multicolumn{2}{|c|}{01 company* } \\
\hline Sole & 06 companies & 02 companies & \multicolumn{2}{|c|}{-} \\
\hline
\end{tabular}

Table 3b: Companies' profile

\begin{tabular}{|l|c|}
\hline \multicolumn{1}{|c|}{ Constructs } & Question Number \\
\hline 1 - Organizational Structure of innovation & 10 and 12 \\
\hline 2 - Culture of innovation & 2 and 14 \\
\hline 3 - Cooperation_for raw material innovation & 3 and 4 \\
\hline 4 - Innovation Strategy & 6 and 11 \\
\hline 5 - Business integration for innovation & 19 and 20 \\
\hline 6 - Technology management & 7 and 8 \\
\hline 7 - Product Development Process & 1 \\
\hline 8 - Innovation in the manufacturing process & 9 \\
\hline 9 - Partnerships for Innovation & 5 \\
\hline 10 - Importance of cooperation for raw material innovation & 16 \\
\hline 11 - Cooperation for product innovation & 15 \\
\hline 12 - Relationships formalization & 13,17 and 18 \\
\hline
\end{tabular}

Table 4: Constructs

ISSN: 07I 8-2724. (http://www.jotmi.org)

Journal of Technology Management \& Innovation (c) Universidad Alberto Hurtado, Facultad de Economía y Negocios. 
scale of I-5.The responses range from: strongly disagree - I to totally agree -5 . In order to test the hypothesis about which of the three tiers of the supply chain is predominant in the innovation process, a questionnaire with twelve constructs was designed, which are listed in Table 4 with their respective measurement scales (questionnaire questions).

The Cronbach's alpha for the constructs with two or more scales was above 0.70 , which is appropriate for the application of multivariate techniques (Hair et al, 200I). For the constructs with only one variable, the univariate analysis was used. Hence, for significance tests with a more than one scale, the multivariate Hotelling's test was used to identify the differences among the three groups of companies. The Kruskall-Wallis test, non-parametric significance test for comparing independent groups, was used for tests with a single scale. The use of non-parametric tests is due to the use of qualitative ordinal scales (Montgomery and Runger, 2003).

\section{Results and analysis}

The characteristics of the companies presented in Table $3 \mathrm{~b}$ indicate that they are mostly small and medium- sized. In general, the shoe and sole companies are between 10 and 20 years old, while the tanneries are mostly over 30 years old. Seventy-five percent of the companies indicated that they adopt the centralized management model, often based on experiences and decisions of their owner-managers; nineteen percent stated that they have a decentralized management structure; and approximately three percent adopt a participatory and centralized management. Some of the respondents commented on the centralization of power and authority of owners. They believe that centralized management is already embedded in the culture of footwear indus- try. It can be said that the companies studied in this cluster still adopt fairly conventional management models, which can hinder the development of joint activities and relationships with other companies in the cluster.

Table 5 shows the significance tests of the groups of companies studied (shoes and sole manufacturers and tanneries) for the twelve constructs. Three constructs showed levels of significance $p<0.10$, indicating statistically significant differences between these groups of companies. Cooperation for raw material innovation and innovation strategies are different between shoe companies and tanneries. The importance of cooperation for raw material innovation is seen differently by the shoe and sole manufacturers.

The tanneries showed greater predisposition to cooperate for raw material innovation than the shoe manufacturers, as shown in Figure 2. In question number 3, it was evaluated the collaborative actions between tanneries and their customers to make more efficient use of the raw materials used to manufacture footwear. In question 4, it was investigated whether the tanneries develop joint activities with other companies to promote innovations in the raw materials used in shoe manufacturing.

The histogram in Figure 2 indicates greater heterogeneity in the opinions about the impact of raw material innovation on competitiveness among the shoe companies than those of the tanneries and sole companies. Question 16 investigates whether innovation in raw material used for shoe manufacturing does not depend on the collaboration between independent companies. Most footwear companies do not agree with that statement, which means that these companies depend more on partnerships to introduce innovations in their products.

\begin{tabular}{lrrr}
\hline \multicolumn{1}{c}{ Constructs } & $\begin{array}{c}\text { Shoe manufacturers - } \\
\text { Tanneries }\end{array}$ & $\begin{array}{c}\text { Shoe and sole } \\
\text { manufacturers }\end{array}$ & $\begin{array}{c}\text { Tanneries - Sole } \\
\text { manufacturers }\end{array}$ \\
\hline 1 - Organizational Structure of innovation & 0.441 & 0.887 & 0.256 \\
\hline 2 - Culture of innovation & 0.437 & 0.907 & 0.682 \\
\hline 3 - Cooperation for raw material innovation & $\underline{0.095}$ & 0.339 & 0.413 \\
\hline 4 - Innovation Strategy & $\underline{0.0733}$ & 0.612 & 0.228 \\
\hline 5 - Business integration for innovation & 0.734 & 0.605 & 0.815 \\
\hline 6 - Technology management & 0.567 & 0.165 & 0.348 \\
\hline 7 - Product Development Process & 1.000 & 1.000 & 1.000 \\
\hline 8 - Innovation in the manufacturing process & 1.000 & 1.000 & 1.000 \\
\hline 9 - Partnerships for Innovation & 1.000 & 0.158 & 0.923 \\
\hline 10 - Importance of cooperation for raw material innovation & 1.000 & $\underline{0.095}$ & 0.414 \\
\hline 11 - Cooperation for product innovation & 1.000 & 1.000 & 1.000 \\
\hline 12 - Relationships formalization & 0.426 & 0.808 & 0.863 \\
\hline
\end{tabular}

Table 5: Constructs' significance tests.

ISSN: 07I 8-2724. (http://www.jotmi.org)

Journal of Technology Management \& Innovation (c) Universidad Alberto Hurtado, Facultad de Economía y Negocios. 
Figure 3 shows the innovation strategies implemented by the corporations studied. Question 6 investigates whether the company invests formally a percentage of the total revenue in product innovation activities. Question II raises the issue of whether the majority of product innovations result from direct requests from clients.

It can be seen in Figures 2 and 3 that clients, shoes manufacturing companies, encourage tanneries to product innovation. On the other hand, the shoe manufacturers companies show different behavior presenting a lower median. Nevertheless, the shoe manufacturers invest more in innovation than tanneries.

As shown in Figure 3, the sole manufacturing companies show opposite behavior. No statistically significant difference was detected between the shoe manufacturers and tanneries. The results show only three constructs but indicate statistically significant differences and demonstrate that the shoe manufacturers play a key role in the cluster innova- tion process. On the other hand, the tanneries are potentially more incorporated into innovation processes than the sole manufacturers.

It can be said that the shoe manufacturers predominate the processes of product innovation in the cluster in the city of Franca, proving that hypothesis is true with a significance level less than 0.10 . This result in the table 6 show discriminate analysis that makes the classification of companies about independents variables (question I to 20). The 95\% correct shoe manufacturers companies of discriminate function confirm hypotheses this research that variables of the local innovation system are asymmetric and explain the characteristics of the local productive chain, in specially about shoe manufacturers - these are more important promotion local innovation.

In concordance with table 6 , that synthesizes the table 7 , we can determinate posterior probabilities of companies' classification local shoes productive chain of Franca, State
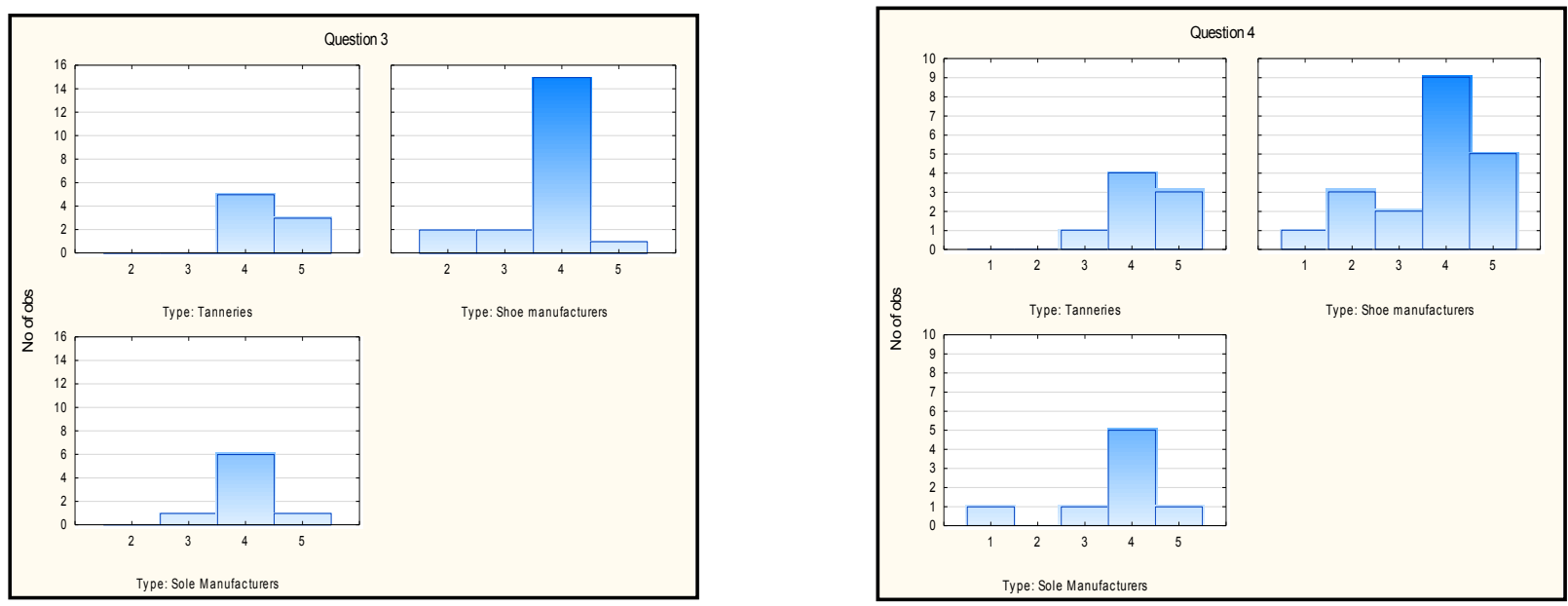

Figure 2: Perceptions of cooperation for raw material innovation, construct 3.
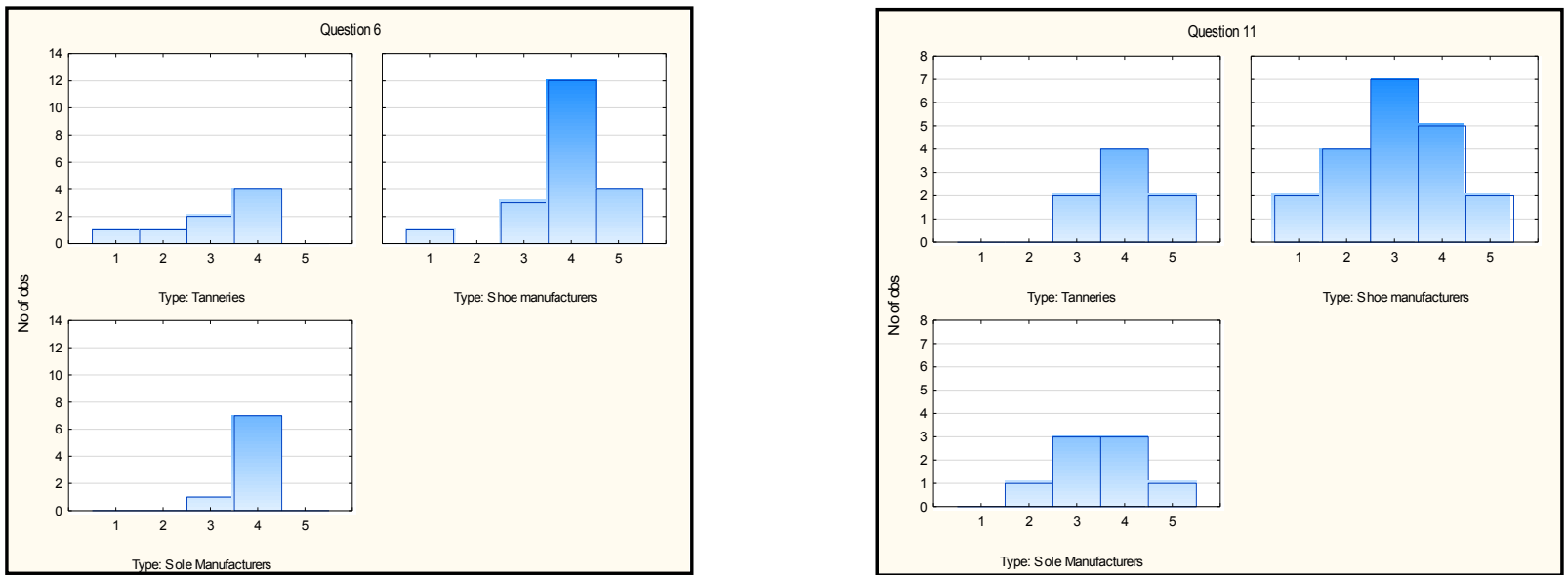

Figure 3: Perceptions of innovation strategy, construct 4.

ISSN: 07 I8-2724. (http://www.jotmi.org)

Journal of Technology Management \& Innovation (C) Universidad Alberto Hurtado, Facultad de Economía y Negocios. 
of São Paulo, Brazil. The model does four incorrect classifications, how we see in the table 7, which, in fact, shows characteristics of the local productive chain how explanatory variables of the local Innovation system. The mains variables showed in the tables 5 and 6 are cooperation for raw material innovation (questions 3 and 4), innovation strategy (questions 6 and $\mathrm{II}$ ), and importance of cooperation for raw material innovation (question 16). Descriptive analyses show perception range about theses question; so, for shoes companies, views with frequently the score five that other type the companies.

\section{Conclusions}

Technological innovation focuses on information and the relationship between technology and society. The knowledge that comes from information is necessary to introduce changes in the businesses and in the production system. This, on the one hand, demands the analysis of internal factors such as skills and tacit and explicit competence; on the other hand, it demands the analysis of external factors represented by the strategic competence to cooperate and integrate with key tiers in the productive chain. The result of this analysis is a series of actions that affect the competitiveness of the company and the chain tiers. A major factor of competitiveness is effective innovation, especially in the context of small and medium-sized enterprises in industrial clusters, such as the footwear companies in the city of Franca.

As previously seen, the process of technological innovation in the cluster in the footwear industry of Franca focuses primarily on strategic actions developed by shoe manufacturers although the tanneries also have technology necessary for promoting innovations. It can be concluded that innovation is driven by footwear companies, but part of this innovation results from the demand for tanning services.

Cultural factors related to the current system of ideas and paradigms, as well as the internal capacity of companies for developing and implementing competitive strategies based on innovation, are determinants of models for local innovation. In the cluster of Franca, companies have historically maintained their competitiveness through innovation in production processes. Some success stories are based on product innovation to old and new markets. There are some exceptions, but they are comparatively few.

A public policy to add value and increase regional competitiveness should focus on the footwear companies' competence for promoting product innovations throughout the productive chain. However, the search for new marketing strategies with new products for new and more demanding market segments will be a catalyst for innovation dynamics of the cluster.As shown by IBGE, the footwear sector is low tech, which can be explained in part by the low value-added market segments in which companies operate. A change in this scenario demands an improvement in the business strategies, especially in the footwear companies, to reap the benefits of production synergies from this unique cluster.

In general, the result this study identifies the shoes manufactories companies as potential business leaders, but there is a lack of development of competitive strategies that make cooperative use of more advanced technologies for product development. The joint actions in this direction need to be more focused on the regional companies. Overcoming this barrier will raise the competitive power to enter new markets, and thus there may be new companies in the production chain and new actors that support local competencies. For instance, we can consider innovation process in the cluster of Franca as a process concentrated in the incremental innovation that should engage the whole local chain, and that are related to the set of abilities that an organization accumulates throughout the time and to the positioning in terms of product/market that it intends to occupy.

From an academic point of view, it is expected that this study contributes to show the improvement of intra-cluster innovation investigative tools considering the local knowledge, the systemic non-linear view presented, the interdisciplinary knowledge, and the local cooperative and integration systems. From a business point of view, this study seeks to reveal the characteristics of the local production system that can be considered in the development of public policies. This study has some data collection limitations. The research tool should be enhanced and in loco interviews should be conducted for firmer conclusions and improved research.

\begin{tabular}{ccccc}
\hline & $\%$ & Tanneries & Shoe manufacturers & Sole Manufacturers \\
\hline Tanneries & 75,0 & 6 & 2 & 0 \\
\hline Shoe manufacturers & 95,0 & 1 & 19 & 0 \\
\hline Sole Manufacturers & 87,5 & 0 & 1 & 7 \\
\hline Total & 88,9 & 7 & 22 & 7 \\
\hline
\end{tabular}

Table 6: Classification matrix.

ISSN: 07 I8-2724. (http://www.jotmi.org) 


\begin{tabular}{|c|c|c|c|c|}
\hline \multirow[b]{2}{*}{ Cases } & \multirow[b]{2}{*}{ Observed Classifications } & \multicolumn{3}{|c|}{ Posterior Probabilities } \\
\hline & & Tanneries & Shoe manufacturers & Sole Manufacturers \\
\hline 1 & Shoe manufacturers & 0,032 & 0,959 & 0,009 \\
\hline 2 & Shoe manufacturers & 0,052 & 0,834 & 0,114 \\
\hline 3 & Shoe manufacturers & 0,001 & 0,986 & 0,013 \\
\hline 4 & Shoe manufacturers & 0,013 & 0,949 & 0,038 \\
\hline 5 & Shoe manufacturers & 0,008 & 0,588 & 0,404 \\
\hline 6 & Shoe manufacturers & 0,000 & 0,990 & 0,010 \\
\hline 7 & Shoe manufacturers & 0,004 & 0,948 & 0,047 \\
\hline 8 & Shoe manufacturers & 0,010 & 0,988 & 0,003 \\
\hline 9 & Shoe manufacturers & 0,000 & 0,986 & 0,013 \\
\hline 10 & Shoe manufacturers & 0,000 & 0,999 & 0,001 \\
\hline 11 & Shoe manufacturers & 0,012 & 0,965 & 0,023 \\
\hline 12 & Shoe manufacturers & 0,001 & 0,999 & 0,000 \\
\hline 13 & Shoe manufacturers & 0,014 & 0,984 & 0,003 \\
\hline 14 & Shoe manufacturers & 0,115 & 0,877 & 0,008 \\
\hline 15 & Shoe manufacturers & 0,000 & 1,000 & 0,000 \\
\hline 16 & Shoe manufacturers & 0,004 & 0,996 & 0,000 \\
\hline$* 17$ & Shoe manufacturers & 0,661 & 0,274 & 0,065 \\
\hline 18 & Shoe manufacturers & 0,000 & 0,999 & 0,001 \\
\hline 19 & Shoe manufacturers & 0,022 & 0,970 & 0,008 \\
\hline 20 & Shoe manufacturers & 0,001 & 0,913 & 0,086 \\
\hline 21 & Tanneries & 0,661 & 0,274 & 0,065 \\
\hline 22 & Tanneries & 0,524 & 0,038 & 0,438 \\
\hline$* 23$ & Tanneries & 0,159 & 0,790 & 0,051 \\
\hline 24 & Tanneries & 0,999 & 0,000 & 0,001 \\
\hline 25 & Tanneries & 0,988 & 0,011 & 0,001 \\
\hline 26 & Tanneries & 1,000 & 0,000 & 0,000 \\
\hline$* 27$ & Tanneries & 0,174 & 0,826 & 0,000 \\
\hline 28 & Tanneries & 0,997 & 0,003 & 0,001 \\
\hline 29 & Sole Manufacturers & 0,374 & 0,029 & 0,597 \\
\hline 30 & Sole Manufacturers & 0,000 & 0,027 & 0,973 \\
\hline 31 & Sole Manufacturers & 0,030 & 0,016 & 0,954 \\
\hline 32 & Sole Manufacturers & 0,006 & 0,349 & 0,645 \\
\hline 33 & Sole Manufacturers & 0,000 & 0,011 & 0,989 \\
\hline 34 & Sole Manufacturers & 0,001 & 0,013 & 0,985 \\
\hline 35 & Sole Manufacturers & 0,000 & 0,001 & 0,999 \\
\hline$* 36$ & Sole Manufacturers & 0,148 & 0,815 & 0,037 \\
\hline
\end{tabular}

Table 7: Classification matrix. Incorrect classifications are marked with *

ISSN: 07 I8-2724. (http://www.jotmi.org)

Journal of Technology Management \& Innovation (C) Universidad Alberto Hurtado, Facultad de Economía y Negocios. 


\section{References}

BAPTISTA, R. (2000). Do innovation diffuse faster within geographical clusters? International Journal of Industrial Organization. I8,3, 5I5-535.

BAS, T. G., Amoros, E., Kunc, M. (2008). Innovation, entrepreneurship and clusters in Latin America natural resource - implication and future challenges, Journal of Technology Management and Innovation. 3,4, 52-65.

BASILEVSKY, A. (1994). Statistical Factor Analysis and Related Methods:Theory and Applications. Wiley Interscience: New York.

BELL, M., Albu, M. (1999). Knowledge Systems and Technological Dynamism in Industrial Clusters in Developing Countries.World Development, 27, 9,. 17/5-1734.

BURGELMAN, R. A., Mandique, M. A., Wheelwright, S. C. (200I). Strategic Management of Technology and Innovation. $3^{a}$ ed., McGraw-Hill Book, Singapure.

CHESBROUGH, H.W. (2003). Open innovation: the new imperative for creating and profiting from technology. HBS Press Book,USA.

FURTADO, A. T., Carvalho, R. Q. (2005). Padrões de intensidade tecnológica da indústria brasileira - um estudo comparativo com países centrais. São Paulo em Perspectiva, 19 , I, I-84.

GHOSH, A., Fedorowicz, J. (2008). The Role of Trust in Supply Chain Governance. Business Process Management Journal, I4, 4, 453-470.

HAIR, J.F., Anderson, R. E., Tatham, R. L., Black, W. C. (200I). Multivariate Data Analysis. Prentice-Hall International, 5.ed, Englewood Cliffs: New Jersey.

HILSDORF, W. C. , Rotondaro, R. G., PIRES, S. R. I. (2009). Integração de processos na cadeia de suprimentos e desempenho do serviço ao cliente: um estudo na indústria calçadista de Franca. Gestão e Produção, 16, 2, 232-244.

HOFFMANN, W. A. M., Gregolin, J.R. and Oprime, P. C. (2004). Development of local productive settlements (clusters): Pre-prospective research of the footwerar settlement of Jau - Brazil. The International Journal of Information Science for Decision Making, 12, 0I-09.

HSU, C., Kannan, V.R., Tan, K., Leong, G.K. (2008). Information sharing buyer-supplier relationships, and firm performance - a multi-region analysis. International Journal of Physical Distribuition and Logistics Management, 38, 4, pp. 296-3I0.
IDRISSIA, M.O.,Amaraa, N., Landrya, R. (20I2). SMEs' Degree of Openness:The Case of Manufacturing Industries. Journal of Technology Management and Innovation. 7, I, pp. I86-2 I0.

IBGE (2008). Pesquisa Industrial - Inovação Tecnológica Pintec, Rio de Janeiro, Finep/MCT/IBGE.

KARAEV, A., Lenny, K.S.C., Szamosi, L.T., (2007). The Cluster approach and SME competitiveness: a review. Journal of Manufacturing Technology Management, 18, 7, 8I 8-835.

KUEI-HSIEN, N., Miles, G., Ghung-Shing, L. (2008). Strategic development of network clusters. Competitiveness Review, $18,3,176-181$.

MASON, C., Castleman, T., Parker, C. (2008). Communities of enterprise: developing regional SMEs in the knowledge economy. Journal of Enterprise Information Management, 2 I, $6,57 I-584$.

MEDORI, D., Steeple, D. (2000) A framework for auditing and enhancing performance measurement systems. International Journal of Operations and Production Management, 20, 5, 520-533.

MOHANNAK, K. (2007). Innovation networks and capability building in the Australian high-technology SMEs, European Journal of Innovation Management, 10, 2, 236-25I.

MONTGOMERY, C. D ., Runger, G. C . (2003.) Estatística aplicada e probabilidade para engenheiros. 2.ed,, LTC: São Paulo.

NEELY, A., Adams, C., Kennerly, M. (2002). The performance prism. Pearson Education Limited: England.

PETRUZZELLI, A.M., Albino V., Carbonara, N. (2007). Technology districts: proximity and knowledge access, Journal of Knowledge Management, I I, 5 pp.98 - II 4

PORTER, M. E. (1999.) Clusters e competitividade. Harvard Business Review, 100-II0.

OECD (2008). Science, Technology and Industry Outlook: Highlights, Paris.

OLIVER, J. L., Porta J. I. D. (2006). How to measure IC in Clusters: empirical evidence. Journal of Intellectual Capital, 7, 3, 354-362.

OPRIME, P., Toledo, J. C., Tristão, H. M., Pimenta, M. L. (2009). Análise de relacionamentos, cooperação e desenvolvimento no cluster industrial de jóias e folheados de Limeira. Revista Produção Online, 9, 4, 65I-675.

ISSN: 07 I8-2724. (http://www.jotmi.org) 
RABELLOTTI, R. (1999) Recovery of a mexican cluster: Devaluation bonanza or collective efficiency? World Development. 27, 9, I57|-I585.

RIIS, J. O., Johansen, J., Waehrens, V. (2007), Strategic roles of manufacturing. Journal of Manufacturing, Technology Management, 18, 8,.983-948.

SCHIUMA, G., Lerro, A. (2008) Knowledge-based capital in building regional innovation capacity. Journal of Knowledge Management. 15, 5, I2I-I36.

SOLVELL, O., Ketels, C., Lindqvist, G. (2008). Industrial specialization and regional clusters in the ten new EU member states. Competitiveness Review: An International Business Journal, 18, I/2, 104-130.

SUZIGAN, W., Furtado J., Garcia, R., Sampaio, E. K. (200I). Sistemas produtivos locais no estado de São Paulo: $O$ caso da indústria de calçados de Franca. Instituto de Pesquisa Econômica Aplicada - IPEA. 268-322.

TOSI, P G. (1998). Capitais no interior: Franca e a história da indústria e comércio calçadista (1860-1945), PhD thesis, Universidade Estadual de Campinas, Campinas, SP.

TRISTÃO, H. M. (2000). Cluster e a cadeia produtiva de calçados de Franca. Facef-série cidade, 3, I, I5-9|.

TRIOLA, M. F. (2005). Introdução à Estatística, 9.ed. LTC: Rio de Janeiro.

VISSER, J.A. (1999). Comparison of clustered and dispersed firms in the small-scale clothing industry Lima,World Development, vol. 27, no.9, pp. I553-I570. 